\title{
RESPON PERKECAMBAHAN DAN PERTUMBUHAN BIBIT WERU (Albizia procera Benth) BERDASARKAN HASIL SELEKSI BENIH
}

\author{
(Response of Germination and Seedling Growth of (Albizia procera Benth) \\ Based on Seed Selection)
}

\author{
Eliya Suita, ${ }^{1)}$ Nurhasybi ${ }^{1)}$ dan/and Darwo ${ }^{2)}$ \\ ${ }^{1)}$ Balai Penelitian Teknologi Perbenihan Tanaman Hutan \\ Jl. Pakuan Ciheuleut Kotak Pos 105 Bogor \\ Telp./Fax. 0251-8327768 \\ Email : eliyasuita@yahoo.co.id \\ ${ }^{2)}$ Pusat Penelitian dan Pengembangan Peningkatan Produktivitas Hutan \\ Jl. Gunung Batu No 5 Kotak Pos 331 Bogor \\ Telp. 0251-8631238; Fax. 0251-7520005 \\ Email: darwo_iph@yahoo.co.id
}

Naskah masuk : 7 Februari 2013; Naskah diterima : 18 November 2013

\begin{abstract}
Quality of seeds is a key for the success of plantation forest development. It is verified by the level of viability, germination, and vigour. The aim of this research is to find out the effect of seed selection on seed germination and seedling growth of weru. Paremeters measured in this research were moisture content, weight for 1,000 seeds, variety of weight and size, germination, and seedling growth. Seed samples were originally collected from Carita, Sumedang and Majalengka. Seed selection was conducted by means of seed gravity table (SGT) and seed sieve in mesh. Data were analyzed using factorial design, i.e. seed origin is for first factor and seed size for second factor. The results revealed that the quality of seeds was apropriate to be selected using SGT with seed size K2 and using seed sieve in mesh in diameter size $>4.7 \mathrm{~mm}$. Seed from Sumedang are relatively higher in gravity, lower moisture content, higher seedling growth in height and diameter, higher viability and germination rate compared to those from Carita and Majalengka.
\end{abstract}

Keyword: Seed, germination, growth, selection, weru

\begin{abstract}
ABSTRAK
Keberhasilan pembangunan hutan tanaman berkaitan erat dengan pengadaan benih bermutu. Salah satu parameter yang memiliki korelasi terhadap mutu benih adalah ukuran benih. Ukuran benih jenis-jenis pohon tertentu berkorelasi dengan viabilitas dan vigor benih, dimana benih yang berat cenderung mempunyai vigor yang lebih baik. Tujuan penelitian ini adalah untuk mengetahui pengaruh seleksi benih terhadap perkecambahan benih dan pertumbuhan bibit weru. Benih diseleksi dengan alat seed gravity table (SGT) dan saringan berukuran mesh. Benih dilakukan seleksi, kemudian diuji kadar air, berat 1.000 butir, perkecambahan dan pertumbuhan bibitnya. Data dianalisis dengan menggunakan Rancangan Faktorial yaitu faktor pertama asal benih dan faktor kedua ukuran benih. Hasil penelitian menunjukkan seleksi benih weru dapat menggunakan alat SGT dengan memilih ukuran benih K2 (kelompok benih 2) dan alat saring berukuran mesh dengan ukuran diameter lebih dari 4,7 mm. Benih weru asal Sumedang menunjukkan mutu benih dan tingkat pertumbuhan bibit yang lebih baik dibandingkan dengan benih weru asal Carita dan Majalengka.
\end{abstract}

Kata kunci: Benih, perkecambahan, pertumbuhan, seleksi, weru 


\section{PENDAHULUAN}

\section{A. Latar Belakang}

Ketersediaan sumberdaya alam terbarukan (renewable) masih belum optimal dipergunakan untuk menyediakan kebutuhan energi. Pemanfaatan sumberdaya ini memungkinkan untuk mengelolanya dalam jangka waktu yang relatif panjang dibandingkan dengan penggunaan sumber energi fosil. Kayu bakar termasuk energi yang paling konvensional dan untuk memanfaatkannya tidak memerlukan teknologi pengolahan yang rumit. Upaya utnuk memenuhi ketersediaan energi terbarukan adalah melalui pembangunan hutan tanaman penghasil kayu energi.

Salah satu jenis kayu energi adalah weru (Albizia procera Benth.). Kayu weru merupakan jenis yang mempunyai kalor yang tinggi yaitu 4.870 Cal/g (Hartoyo dan Nurhayati, 1976), sehingga dapat dijadikan sebagai penghasil kayu energi. Weru tumbuh di Pulau Jawa pada ketinggian kurang dari 1.200 meter dari permukaan laut dan di daerah lain umumnya tumbuh berkelompok. (Heyne, 1987). Jenis ini berasal dari Australia dan Oceania yang menyebar ke Papua Nugini, Asia Tenggara, Asia Selatan (Syamsuwida, 2001). Menurut Sudrajat (2008), jenis ini tumbuh baik pada tanah aluvial dengan drainase baik atau tanah liat yang relatif dalam, kering berbatu dan tanah berpasir.

Untuk mendukung keberhasilan penanaman, diperlukan penyediaan benih bermutu. Permasalahan yang muncul dalam rangka pengadaan benih adalah menentukan cara seleksi/sortasi benih yang efektif untuk memilih benih-benih bermutu fisiologis tinggi. Menurut Schmidt (2000), ukuran benih berkorelasi dengan viabilitas dan vigor benih, dimana benih yang berat cenderung mempunyai vigor yang lebih baik. Sorensen dan Campbell (1993), menyata-kan ukuran benih dalam bentuk berat dan ukuran dimensi yang lebih besar lebih banyak dipilih karena umumnya berhubungan dengan kecepatan berkecambah dan perkembangan semai yang lebih baik, tetapi ini akan membuang benih berukuran lebih kecil yang mungkin mempunyai genetik lebih baik.

Variasi berat dan ukuran benih dipengaruhi oleh faktor keturunan (genetik) dan lingkungan. Ada dugaan bahwa benih berukuran besar memberikan keuntungan fisiologis karena persediaan cadangan makanan yang lebih mencukupi untuk perkecambahan daripada ukuran benih yang lebih kecil. Untuk itu, kondisi benih tersebut perlu diteliti. Diharapkan adanya klasifikasi ukuran benih ini akan memperbaiki kualitas fisiologis lot benih yang dapat menjamin perkecambahan dan pertumbuhan bibit yang lebih baik, sehingga upaya tersebut akan meningkatkan keberhasilan persemaian dalam rangka menyediakan bibit bermutu untuk kegiatan penanaman.

\section{B. Tujuan}

Penelitian ini bertujuan untuk mengetahui pengaruh seleksi benih terhadap perkecambahan benih dan pertumbuhan bibit weru.

\section{METODE PENELITIAN}

\section{A. Bahan dan Peralatan}

Bahan yang diperlukan adalah benih weru (A. procera Benth.) dari tiga lokasi, media perkecambahan (pasir dan tanah $(1: 1)(\mathrm{v} / \mathrm{v}))$, dan media pembibitan (tanah + arang sekam padi $(1: 1)(\mathrm{v} / \mathrm{v}))$. Peralatan yang digunakan meliputi bak kecambah, oven, timbangan analitik, kamera, penggaris, kaliper, ayakan (mesh), seed gravity table (SGT), label, kantong plastik, polybag, shading net dan lain-lain.

\section{B. Tahapan Penelitian}

\section{Ekstraksi}

Benih yang digunakan adalah benih yang sudah masak fisiologi, yang ditandai dengan warna buah hijau-kecokelatan dan sebagian buah sudah merekah. Benih diunduh, kemudian diekstraksi untuk mengeluarkan benih dari buahnya. Ekstraksi dilakukan dengan cara buah dijemur sampai merekah, kemudian benih dimasukkan ke dalam karung, dan dipukul-pukul atau diinjakinjak, sampai benih terpisah dari kulitnya.

\section{Pengujian kadar air benih}

Kadar air dinyatakan dalam persen berat dan dihitung dengan rumus (ISTA, 2006) :

$$
\text { Kadar air }=\frac{(\mathrm{M} 2-\mathrm{M} 3)}{(\mathrm{M} 2-\mathrm{M} 1)}
$$

dimana: $\quad$ M1 = berat wadah dan penutup dalam gram; M2 = berat wadah, penutup, dan benih sebelum pengeringan; $\mathrm{M} 3$ = berat wadah, penutup, dan benih sesudah pe-ngeringan. Pengujian kadar air meng-gunakan 3 ulangan dan masing-masing setiap ulangan@5 gram benih. 


\section{Penentuan berat 1.000 butir benih}

Penentuan berat 1.000 butir benih dengan cara menimbang 100 butir benih secara acak yang diulang 8 kali. Dari berat rata-rata 100 butir benih, kemudian dikalikan 10.

Tujuan dari penentuan berat adalah untuk menghitung berat 1.000 butir benih. Penghitungan ini dengan mudah diubah ke dalam bentuk jumlah benih per kilogram (DPTH, 2002)

\section{Seleksi/sortasi berdasarkan berat dan ukuran}

a. Seleksi berdasarkan berat benih (dengan meng-gunakan seed gravity table) :

Alat seed gravity table diatur sebagai berikut: Kemiringan $=$ horizontal $0^{\circ}$ dan vertikal $1^{\circ}$; skala hembusan $=5$ getaran/detik; curah umpan $=110 \mathrm{~mm} /$ detik; kecepatan getaran $=$ $350 \mathrm{~mm} /$ detik.

Benih hasil seleksi, berdasarkan alat Seed Gravity Table, dikelompokkan ke dalam empat kelas ukuran benih yaitu: kelompok benih 1 (K1), kelompok benih 2 (K2), kelompok benih 3 (K3), dan kelompok benih 4 (K4).

b. Seleksi berdasarkan ukuran benih (dengan menggunakan saringan $/$ mesh):

Seleksi benih dengan menggunakan saringan/ mesh, menggunakan ukuran diameter mesh 4,7 $\mathrm{mm}$ dan $4 \mathrm{~mm}$, dimana benih yang tertahan di mesh yang berdiameter $4,7 \mathrm{~mm}$ termasuk benih besar, benih yang tertahan di mesh berdiameter 4 $\mathrm{mm}$ termasuk benih sedang dan benih yang lolos pada mesh berdiameter $4 \mathrm{~mm}$ termasuk benih kecil. Kriteria ukuran benih, yaitu $\mathrm{B} 1=$ ukuran besar (diameter $>4,7 \mathrm{~mm}$ ), B2 = ukuran sedang (diameter 4-4,7 mm), dan B3 = ukuran kecil (diameter $<4 \mathrm{~mm}$ ).

Benih-benih yang sudah diklasifikasikan sesuai kriteria benih, masing-masing ditimbang untuk mengetahui persentasenya, diuji kadar air, berat 1.000 butir dan ditabur/dikecambahkan pada bak kecambah dengan media pasir dan tanah $(1: 1, \mathrm{v} / \mathrm{v})$, masing-masing perlakuan terdiri dari 100 benih dengan 4 ulangan. Pengamatan terhadap perkecambahan dilakukan setiap 2 hari sekali dengan mencatat jumlah kecambah normal yang tumbuh. Kriteria kecambah normal adalah telah munculnya sepasang daun dan bebas dari serangan hama/penyakit (DPTH, 2002). Pengamatan diakhiri setelah 10 hari berturut-turut tidak terdapat lagi pertumbuhan kecambah normal. Hasil dari kecambah normal dipindahkan ke polybag dengan media tanah + arang sekam (1:1, $\mathrm{v} / \mathrm{v}$ ), dengan jumlah ulangan 4 unit contoh, dan setiap ulangan ada 10 amatan.

\section{Parameter}

Parameter yang diukur/diamati terdiri dari :

a. Kadar air,

b. Berat 1.000 butir,

c. Variasi berat/ukuran benih (persentase setiap kelas ukuran/berat benih),

d. Perkecambahan benih (daya berkecambah dan kecepatan berkecambah).

Daya berkecambah ditentukan dengan jumlah benih yang sudah berkecambah normal. Menurut Sadjad et al. (1999), daya berkecambah menjabarkan parameter viabilitas potensial dengan rumus daya berkecambah (DB) adalah :

$$
\mathrm{DB}=\sum \frac{\mathrm{KN}}{\mathrm{N}} \times 100 \%
$$

dimana: $\quad \sum \mathrm{KN}=$ jumlah benih yang menjadi kecambah normal sampai hari ke-60; $\mathrm{N}=$ jumlah benih yang ditabur.

Kecepatan berkecambah yang dihitung adalah benih yang berkecambah dari hari pengamatan pertama sampai dengan hari terakhir. Dengan penghitungan kecambah normal pada setiap pengamatan dibagi dengan etmal ( 1 etmal $=24 \mathrm{jam})$. Menurut Sadjad et al. (1999), kecepatan berkecambah menjabarkan parameter vigor dan rumus Kecepatan berkecambah sebagai berikut :

$$
\mathrm{KCT}=\sum_{i=1}^{n} \frac{(\mathrm{KN}) \mathrm{i}}{\mathrm{Wi}}
$$

dimana: $\mathrm{i}=$ hari pengamatan; $\mathrm{KN}_{\mathrm{i}}=$ kecambah normal pada hari ke-i (\%); $\mathrm{W}_{\mathrm{i}}=$ Waktu (etmal) pada hari ke-i.

e. Pertumbuhan bibit (tinggi dan diameter) untuk bibit hasil seleksi dan hasil penyapihan, diukur setiap satu bulan selama tiga bulan.

\section{A. Analisis data}

Data dianalisis dengan Rancangan Faktorial dalam Rancangan Acak Lengkap Asal Benih x Ukuran Benih. Uji-Tukey digunakan untuk membandingkan nilai rata-rata antar kelas ukuran benih.

\section{HASIL DAN PEMBAHASAN}

\section{A. Hasil}

1. Persentase berat benih pada masing-masing kelompok berat (K) 

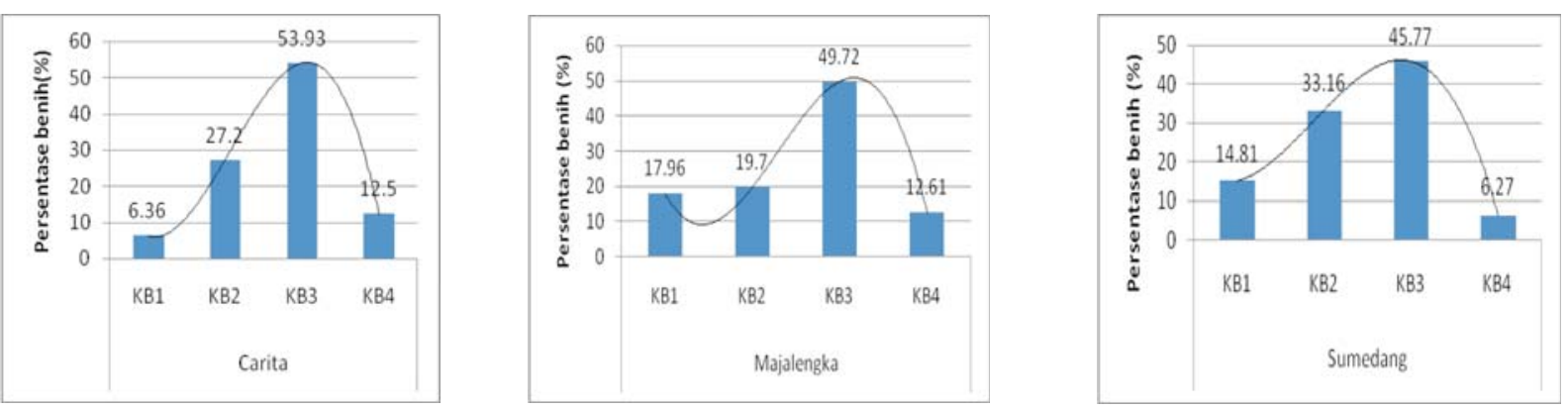

Gambar(Figure) 1. Persentase benih weru hasil seleksi SGT (Percentage of weru seed selected by using seed gravity table $S G T$ )

Dari hasil pengujian, apabila benih diseleksi dengan menggunakan alat SGT, persentase jumlah benih yang terbanyak terdapat pada kelompok benih 3 (K3), sedangkan persentase yang sedikit didapatkan pada kelompok benih 1 (K1) dan kelompok benih 4 (K4). Dari Gambar 1 di atas dapat dilihat bahwa persentase benih dari ketiga lokasi berupa kurva normal yang miring ke kanan yang persentase tertinggi terdapat pada kelompok benih $3(\mathrm{~K} 3)$. Jadi rata-rata ukuran benih terdapat pada kelompok benih 3 (K3) (Gambar 1).
Apabila diseleksi dengan menggunakan saringan dalam ukuran mesh, persentase jumlah benih yang terbanyak didapatkan pada ukuran diameter 4-4,7 mm. (Gambar 2)

Benih weru, yang diseleksi dengan $S G T$ atau alat saringan (mesh), persentase jumlah benih sesuai dengan ukuran/berat benih tidak tersebar merata, dimana benih yang diseleksi dengan $S G T$ yang berukuran $\mathrm{K} 3$ mempunyai persentase yang lebih besar (Gambar 1), dan benih yang diseleksi dengan Mesh yang berukuran diameter 4-4,7 mm mempunyai persentase yang lebih besar (Gambar 2).

b. Analisis keragaman berat 1.000 butir, kadar air, daya berkecambah, kecepatan berkecambah, pertumbuhan tinggi dan diameter bibit
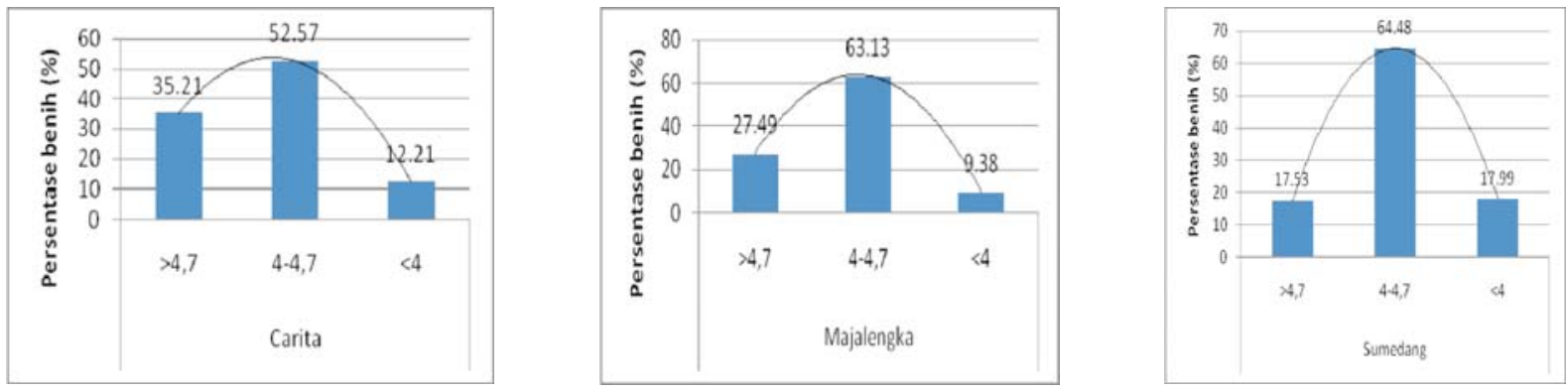

Gambar(Figure) 2. Persentase benih weru hasil seleksi mesh (Percentage of weru seed selected using seed sieve in mesh) 
Tabel (Table) 1. Rekapitulasi hasil analisis keragaman berat 1.000 butir dan kadar air benih weru terhadap alat seleksi benih menggunakan SGT dan alat saringan/mesh (Recapitulation of variety analysis on 1,000 weight seed and moisture content of weru seed based on seed selected using SGT and mesh)

\begin{tabular}{|c|c|c|c|c|}
\hline \multirow[b]{2}{*}{ Parameter (Variables) } & \multicolumn{2}{|c|}{ SGT } & \multicolumn{2}{|c|}{ Saringan (Mesh) } \\
\hline & $\begin{array}{c}\text { Berat } 1.000 \\
\text { butir benih } \\
(1,000 \text { weight } \\
\text { seed })\end{array}$ & $\begin{array}{c}\text { Kadar air } \\
\text { (Moisture } \\
\text { content) }\end{array}$ & $\begin{array}{l}\text { Berat } 1.000 \text { butir } \\
\text { benih }(1,000 \\
\text { weight seed })\end{array}$ & $\begin{array}{l}\text { Kadar air } \\
\text { (Moisture } \\
\text { content) }\end{array}$ \\
\hline Asal benih (Provenance) & $* *$ & $* *$ & $* *$ & $* *$ \\
\hline Ukuran (Size) & $* *$ & $* *$ & $* *$ & $* *$ \\
\hline $\begin{array}{l}\text { Asal benih x Ukuran benih } \\
\text { (Provenance } x \text { Seed size) }\end{array}$ & $* *$ & $* *$ & $* *$ & $* *$ \\
\hline
\end{tabular}

Keterangan $($ Remarks $): * *=$ berbeda sangat nyata, $\mathrm{tn}=$ tidak berbeda nyata pada tingkat nyata $(\alpha=5 \%)(* *=$ very different significantly, $t=$ different not significantly on degree $(\alpha=5 \%))$

Hasil analisis statistik menunjukkan bahwa ada perbedaan yang signifikan antar level dalam faktor asal benih dan antar level dalam faktor ukuran benih berdasarkan SGT maupun ukuran saringan (mesh) terhadap berat 1.000 butir dan kadar air benih weru. Begitu juga ada pengaruh interaksi yang signifikan antara asal benih dengan ukuran benih berdasarkan SGT maupun alat saringan (mesh) (Tabel 1).

Hasil analisis statistik menunjukkan bahwa antar level dalam faktor asal benih, antar level dalam faktor ukuran benih, dan interaksinya telah berpengaruh secara signifikan terhadap tinggi dan diameter bibit weru jika menggunakan ukuran benih berdasarkan seleksi dengan alat seed gravity table. Jika menggunakan alat seleksi benih saringan/mesh ternyata faktor asal benih dan ukuran benih menunjukkan adanya pengaruh yang signifikan, sedangkan interaksinya tidak berpengaruh (Tabel 2).

Hasil analisis statistik menunjukkan bahwa ukuran benih berdasarkan seleksi alat seed gravity table, maka antar level dalam faktor asal benih dan antar level dalam faktor ukuran benih berpengaruh secara signifikan terhadap daya kecambah dan kecepatan berkecambah benih

Tabel(Table) 2. Rekapitulasi hasil analisis keragaman tinggi dan diameter bibit weru berdasarkan alat seleksi benih SGT dan alat saringan/mesh (Recapitulation of variety analysis on height and diameter of seedling of weru based on seed selected using SGT and seed sieve in mesh)

\begin{tabular}{|c|c|c|c|c|}
\hline \multirow[b]{2}{*}{ Parameter } & \multicolumn{2}{|c|}{ SGT } & \multicolumn{2}{|c|}{ Saringan (Mesh) } \\
\hline & $\begin{array}{l}\text { Tinggi bibit } \\
\text { (Seedling } \\
\text { height })(\mathrm{cm})\end{array}$ & $\begin{array}{l}\text { Diameter bibit } \\
\quad(\text { Seedling } \\
\text { diameter })(\mathrm{mm})\end{array}$ & $\begin{array}{l}\text { Tinggi bibit } \\
\text { (Seedling } \\
\text { height })(\mathrm{cm})\end{array}$ & $\begin{array}{l}\text { Diameter bibit } \\
(\text { Seedling } \\
\text { diameter })(\mathrm{mm})\end{array}$ \\
\hline $\begin{array}{l}\text { Asal benih } \\
\text { (Provenance) }\end{array}$ & $* *$ & $* *$ & $* *$ & $* *$ \\
\hline $\begin{array}{l}\text { Ukuran benih (Seed } \\
\text { size) }\end{array}$ & $* *$ & $* *$ & $* *$ & $* *$ \\
\hline $\begin{array}{l}\text { Asal benih x Ukuran } \\
\text { benih (Provenance } x \\
\text { seed size) }\end{array}$ & $* *$ & $* *$ & $* *$ & th \\
\hline
\end{tabular}

Keterangan $($ Remarks $): * *=$ berbeda sangat nyata, tn $=$ tidak berbeda nyata pada tingkat nyata $(\alpha=5 \%)(* *=$ very different significantly, $t n=$ different not significantly on degree $(\alpha=5 \%))$ 
weru, serta ada pengaruh interaksi secara signifikan. Namun jika menggunakan ukuran benih berdasarkan alat saringan/mesh ternyata yang berpengaruh secara signifikan hanya asal benih, sedangkan ukuran benih dan interaksi tidak berpengaruh nyata (Tabel 3).

Hasil analisis plot interaksi antar asal benih dan ukuran benih berdasarkan alat seleksi SGT terhadap berat 1.000 butir dan kadar air benih weru terjadi interaksi yang signifikan (Gambar 3 dan 4). Hasil uji lanjut asal benih pada $\mathrm{K} 1, \mathrm{~K} 2$, dan K3 menunjukkan bahwa berat 1.000 butir benih weru antar asal benih Carita, Majalengka, dan Sumedang berbeda secara signifikan. Berat 1.000 butir benih weru asal benih pada K4 me- nunjukkan bahwa asal benih Sumedang dengan Carita dan Majalengka berbeda secara signifikan, sedangkan antar asal benih Carita dengan Majalengka tidak berbeda secara signifikan. Selanjutnya asal benih pada K1 dan K4 menunjukkan bahwa kadar air asal benih Sumedang berbeda secara signifikan dengan kadar air asal benih Carita dan Majalengka, namun kadar air asal benih Carita dengan Majalengka tidak berbeda nyata. Asal benih pada K2 dan K3 menunjukkan bahwa kadar antar asal benih Carita, Majalengka, dan Sumadang berbeda secara signifikan. Kadar air benih asal Sumedang termasuk yang terendah. Rekapitulasi hasil uji lanjut disajikan pada Tabel 4.

Tabel (Table) 3. Rekapitulasi hasil analisis keragaman daya kecambah dan kecepatan berkecambah benih weru berdasarkan alat seleksi benih menggunakan SGT dan alat saringan/mesh (Recapitulation of variety analysis on germination percentage and speed of germination of weru based on seed selected using SGT and seed sieve in mesh)

\begin{tabular}{lcccc}
\hline & \multicolumn{2}{c}{ SGT } & \multicolumn{2}{c}{ Saringan $($ Mesh $)$} \\
\cline { 2 - 5 } Parameter & $\begin{array}{c}\text { Daya kecambah } \\
\text { (Germination } \\
\text { percentage) }\end{array}$ & $\begin{array}{c}\text { Kecepatan } \\
\text { berkecambah } \\
\text { (Speed of } \\
\text { germination) }\end{array}$ & $\begin{array}{c}\text { Daya kecambah } \\
\text { (Germination } \\
\text { percentage) }\end{array}$ & $\begin{array}{c}\text { Kecepatan } \\
\text { berkecambah } \\
\text { (Speed of } \\
\text { germination) }\end{array}$ \\
\hline $\begin{array}{l}\text { Asal benih (Provenance) } \\
\text { Ukuran benih (Seed size) }\end{array}$ & $* *$ & $* *$ & $* *$ & $* *$ \\
Asal benih x Ukuran benih & $* *$ & $* *$ & th & th \\
(Provenance x seed size) & $* *$ & $* *$ & tn & th \\
\hline
\end{tabular}

Keterangan $($ Remarks $): * *=$ berbeda sangat nyata, $\mathrm{tn}=$ tidak berbeda nyata pada tingkat nyata $(\alpha=5 \%)(* *=v e r y$ different significantly, $t \mathrm{t}=$ different not significantly on degree $(\alpha=5 \%)$

Tabel (Table) 4. Rekapitulasi hasil uji-Tukey untuk rata-rata berat 1.000 butir (gram) dan kadar air benih weru dengan menggunakan alat SGT (Recapitulation of Tukey test for the average of 1,000 weight seed (grams) and moisture content of weru seed using SGT)

\begin{tabular}{|c|c|c|c|c|c|c|c|c|}
\hline \multirow[t]{2}{*}{$\begin{array}{c}\text { Asal benih } \\
\text { (Provenances) }\end{array}$} & \multicolumn{4}{|c|}{$\begin{array}{c}\text { Berat } 1.000 \text { butir pada ukuran SGT } \\
(1,000 \text { weight seed on seed } \\
\text { size usingSGT) }\end{array}$} & \multicolumn{4}{|c|}{$\begin{array}{l}\text { Kadar air benih (\%) pada ukuran SGT } \\
\text { (Seed moisture content } \\
\text { seed size using SGT) }\end{array}$} \\
\hline & $\mathrm{K} 1$ & K2 & K3 & K4 & K1 & $\mathrm{K} 2$ & K3 & K4 \\
\hline Carita & $2,9601 \mathrm{c}$ & $2,8429 \mathrm{c}$ & $2,6507 \mathrm{c}$ & $2,3353 \mathrm{~b}$ & $12,83 \mathrm{a}$ & $12,72 \mathrm{a}$ & $13,48 \mathrm{a}$ & $13,87 \mathrm{a}$ \\
\hline Majalengka & $3,5637 \mathrm{~b}$ & $3,5565 \mathrm{~b}$ & $3,2203 \mathrm{a}$ & $2,3587 \mathrm{~b}$ & $13,85 \mathrm{a}$ & $11,57 \mathrm{~b}$ & $12,03 \mathrm{~b}$ & $13,55 \mathrm{a}$ \\
\hline Sumedang & $3,7755 \mathrm{a}$ & $3,7932 \mathrm{a}$ & $3,1265 \mathrm{~b}$ & $2,4536 \mathrm{a}$ & $9,15 \mathrm{~b}$ & $9,03 \mathrm{c}$ & $9,88 \mathrm{c}$ & $12,53 \mathrm{~b}$ \\
\hline
\end{tabular}




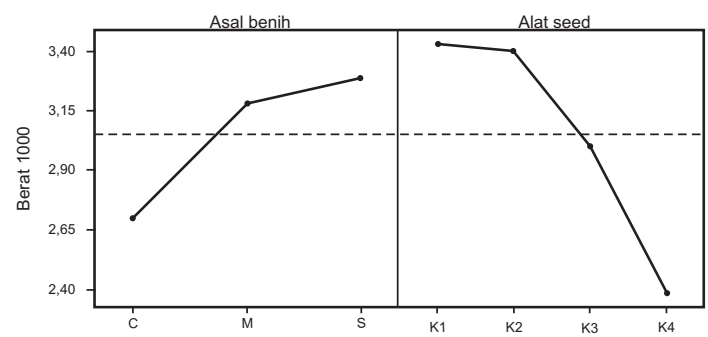

Plot faktor utama (Plot of main factor)

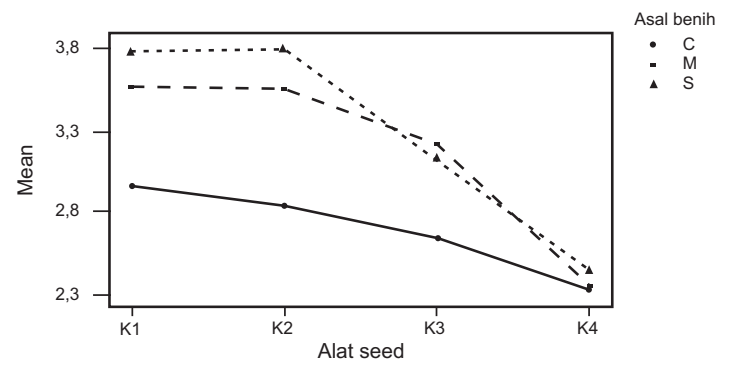

Plot interaksi antar faktor (Plot of interaction between factors)

Gambar(Figure) 3. Plot faktor utama dan interaksi antar faktor terhadap berat 1.000 butir benih weru berdasarkan seleksi SGT (Plot of main factor and interaction between factors for 1,000 weight seed on seed size using SGT)

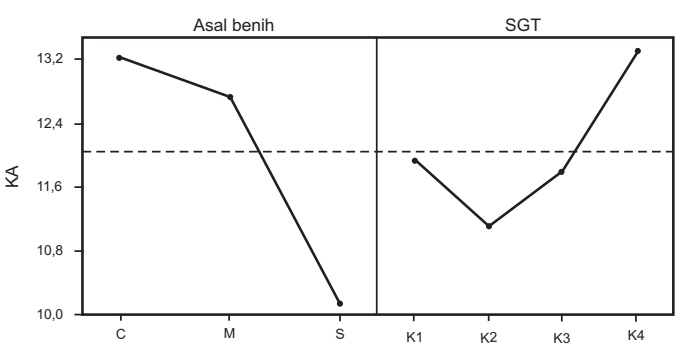

Plot faktor utama (Plot of main factor)

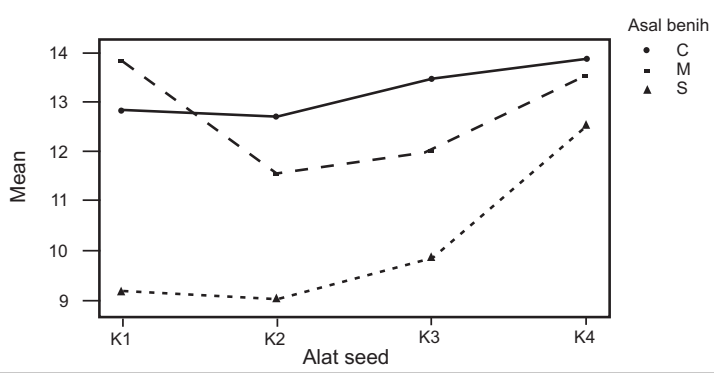

Plot interaksi antar faktor (Plot of interaction between factors)

Gambar(Figure) 4. Plot faktor utama dan interaksi antar faktor terhadap kadar air benih weru berdasarkan seleksi SGT (Plot of main factor and interaction between factors for moisture content of weru seed on seed size using SGT)

Berat 1.000 butir benih weru yang diseleksi dengan alat SGT, tertinggi terdapat pada benih asal Sumedang, kemudian diikuti Majalengka dan Carita, dengan kriteria benih terberat pada ukuran K1 kemudian menurun hingga yang teringan pada K4. Kadar air benih weru yang diseleksi dengan alat SGT, terendah terdapat pada benih asal Sumedang, kemudian diikuti Majalengka dan Carita, dengan kriteria benih kadar air tertinggi pada ukuran K4, sedangkan K1, K2 dan K3 di bawah rata-rata.

Hasil analisis plot interaksi antar asal benih dan ukuran benih berdasarkan alat seleksi saringan (mesh) terhadap berat 1.000 butir dan kadar air benih weru terjadi interaksi yang signifikan (Gambar 5 dan 6). Hasil uji lanjut asal benih pada ukuran saringan $<4,4-4,7$ dan $>4,7$ menunjuk- kan bahwa berat 1.000 butir benih weru asal benih Carita, Majalengka, dan Sumedang berbeda secara signifikan. Selanjutnya, asal benih pada ukuran saringan $<4$ menunjukkan bahwa kadar air Sumedang berbeda secara signifikan dengan kadar air benih asal Carita dan Majalengka. Asal benih pada ukuran 4-4,7 menunjukkan bahwa kadar air benih asal Majalengka berbeda secara signifikan dengan kadar air benih asal Carita dan Sumedang, namun kadar air benih asal Sumedang dengan Carita tidak berbeda secara signifikan. Asal benih pada ukurang $>4,7$ menunjukkan bahwa kadar air antar asal benih Carita, Majalengka, dan Sumedang berbeda secara signifikan. Kadar air asal benih Sumedang termasuk yang terendah. Rekapitu-lasi hasil uji lanjut disajikan pada Tabel 5 . 
Tabel(Table) 5. Rekapitulasi hasil uji Tukey untuk rata-rata berat 1.000 butir benih (gram) dan kadar air benih weru dengan menggunakan alat saringan (mesh) (Recapitulation of Tukey test for the average of 1,000 weight seed (grams) and moisture content of weru seed using seed sieve in mesh)

\begin{tabular}{|c|c|c|c|c|c|c|}
\hline \multirow[t]{2}{*}{$\begin{array}{c}\text { Asal benih } \\
\text { (provenances) }\end{array}$} & \multicolumn{3}{|c|}{$\begin{array}{c}\text { Berat } 1.000 \text { butir pada ukuran saringan } \\
(\mathrm{mm})(1,000 \text { weight of seed by using } \\
\text { wire }(\mathrm{mm}))\end{array}$} & \multicolumn{3}{|c|}{$\begin{array}{c}\text { Kadar air benih (\%) pada ukuran saringan } \\
(\mathrm{mm})(\text { seed moisture content }(\%) \text { on wire } \\
\text { size }(\mathrm{mm})\end{array}$} \\
\hline & $<4$ & $4-4,7$ & $>4,7$ & $<4$ & $4-4,7$ & $>4,7$ \\
\hline Carita & $2,0693 \mathrm{c}$ & $2,6019 \mathrm{c}$ & $3,0811 \mathrm{c}$ & $10,95 \mathrm{a}$ & $10,76 \mathrm{a}$ & $10,93 \mathrm{a}$ \\
\hline Majalengka & $2,2699 \mathrm{~b}$ & $3,2037 \mathrm{~b}$ & $3,7179 \mathrm{a}$ & $11,19 \mathrm{a}$ & $10,14 \mathrm{~b}$ & $10,53 \mathrm{~b}$ \\
\hline Sumedang & $2,6595 \mathrm{a}$ & $3,2433 \mathrm{a}$ & $4,1224 b$ & $8,93 \mathrm{~b}$ & $9,36 \mathrm{a}$ & $9,68 \mathrm{c}$ \\
\hline
\end{tabular}

Catatan (Note): Angka yang diikuti oleh huruf yang sama pada kolom yang sama tidak berbeda nyata pada tingkat kepercayaan 95\% (Figure followed by the same letters at column the same are not significantly different at $95 \%$ confident level)

Berat 1.000 butir benih weru yang diseleksi dengan alat mesh, tertinggi juga terdapat pada benih asal Sumedang, yang diikuti asal benih Majalengka dan Carita. Kategori benih terberat yaitu benih berukuran $>4,7 \mathrm{~mm}$ dan teringan pada benih berukuran $<4 \mathrm{~mm}$. Kadar air benih

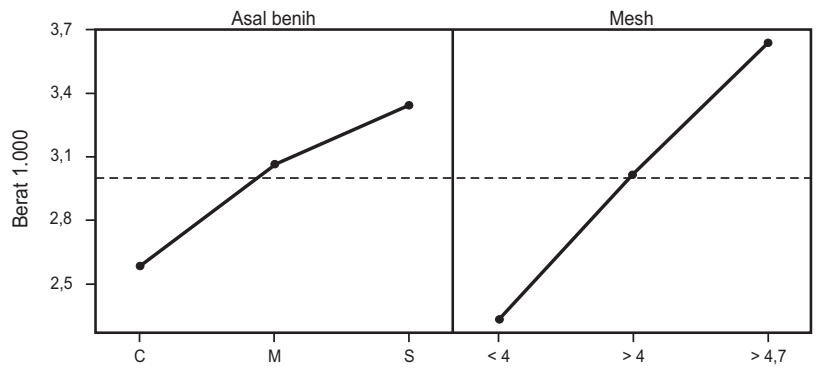

Plot faktor utama

(Plot of main factor) weru yang diseleksi dengan alat saringan/mesh yang terendah untuk benih asal Sumedang, kemudian diikuti Majalengka dan Carita. Ukuran benih untuk $<4 \mathrm{~mm}$ dan $>4,7 \mathrm{~mm}$ mempunyai kadar air di atas rata-rata, sedangkan ukuran benih antara 4-4,7 $\mathrm{mm}$ di bawah rata-rata.

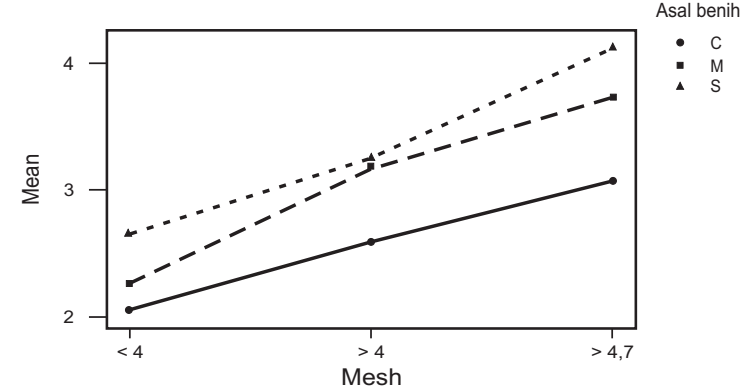

Plot interaksi antar faktor faktor (Plot of interaction between factors)

Gambar(Figure) 5. Plot faktor utama dan interkasi antar faktor terhadap berat 1.000 butir benih weru berdasarkan seleksi saringan (Plot of main factor and Interaction between factors for 1,000 weight seed of weru on seed size using seed sieve in mesh)

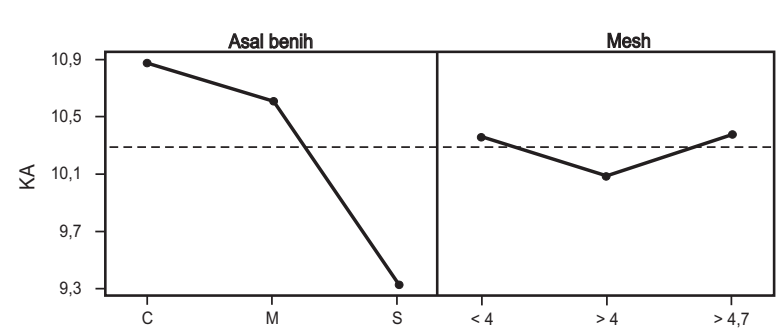

Plot faktor utama (Plot of main factor)

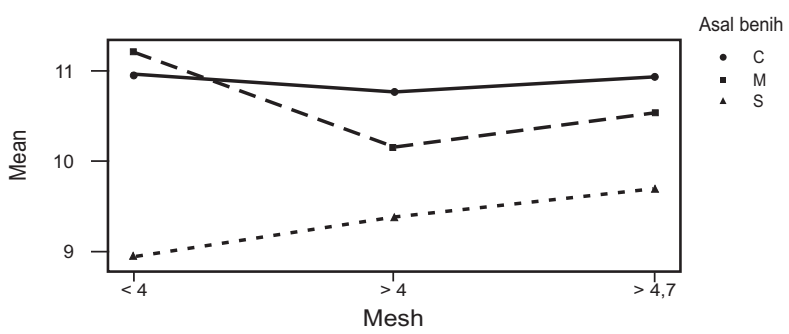

Plot interkasi antar faktor (Plot of interaction between factors)

Gambar(Figure) 6. Plot faktor utama dan interkasi antar faktor terhadap kadar air benih weru berdasarkan seleksi alat saringan (Plot of main factor and interaction between factors for moisture content of weru seed on seed size using seed sieve in mesh) 
Tabel(Table) 6. Rekapitulasi hasil uji Tukey untuk rata-rata pertumbuhan tinggi dan diameter bibit weru berdasarkan klasifikasi ukuran benih menggunakan alat SGT (Recapitulation of Tukey test for the average of seedling height and diameter based on seed size classification using $S G T$ )

\begin{tabular}{|c|c|c|c|c|c|c|c|c|}
\hline \multirow[t]{2}{*}{$\begin{array}{c}\text { Asal benih } \\
\text { (Provenances) }\end{array}$} & \multicolumn{4}{|c|}{$\begin{array}{l}\text { Tinggi bibit untuk ukuran SGT } \\
\text { (Sedling height on seed size } \\
\text { selected by using } S G T \text { ) }\end{array}$} & \multicolumn{4}{|c|}{$\begin{array}{l}\text { Diameter bibit untuk ukuran SGT } \\
\text { (Seedling diameter on seed size } \\
\text { selected by using SGT) }\end{array}$} \\
\hline & $\mathrm{K} 1$ & $\mathrm{~K} 2$ & $\mathrm{~K} 3$ & K4 & K1 & $\mathrm{K} 2$ & K3 & K4 \\
\hline Carita & $9,150 \mathrm{~b}$ & $9,395 \mathrm{~b}$ & $8,817 \mathrm{~b}$ & $7,988 \mathrm{a}$ & $1,270 \mathrm{~b}$ & $1,203 \mathrm{~b}$ & $1,223 \mathrm{a}$ & $1,063 \mathrm{~b}$ \\
\hline Majalengka & $12,150 \mathrm{a}$ & $11,333 \mathrm{a}$ & $11,638 \mathrm{a}$ & $9,475 \mathrm{a}$ & $1,375 \mathrm{ab}$ & $1,283 \mathrm{a} b$ & $1,355 \mathrm{a}$ & $1,340 \mathrm{a}$ \\
\hline Sumedang & $11,810 \mathrm{a}$ & $12,925 \mathrm{a}$ & $12,088 \mathrm{a}$ & $8,323 \mathrm{a}$ & $1,483 \mathrm{a}$ & $1,530 \mathrm{a}$ & $1,475 \mathrm{a}$ & $1,228 \mathrm{ab}$ \\
\hline
\end{tabular}

Catatan (Note): Angka yang diikuti oleh huruf yang sama pada kolom yang sama tidak berbeda nyata pada tingkat kepercayaan 95\% (Figure followed by the same letters at column the same are not significantly different at $95 \%$ confident level)

Hasil analisis plot interaksi antar asal benih dan alat seleksi benih dengan menggunakan SGT terhadap tinggi dan diameter bibit weru terjadi interaksi yang signifikan (Gambar 7 dan 8). Hasil uji lanjut asal benih pada K1, K2, dan K3 menunjukkan bahwa tinggi bibit asal benih Carita berbeda secara signifikan dengan asal benih Majalengka dan Sumedang, sedangkan asal benih Sumedang dengan Majalengka tidak berbeda nyata. Asal benih pada K4 tidak memberikan respon pertumbuhan tinggi yang siginifikan. Diameter bibit weru asal benih pada K1dan K2 menunjukkan bahwa diameter bibit asal benih
Sumedang berbeda secara signifikan dengan asal benih Carita, sedangkan asal benih Sumedang dengan Majalengka dan asal benih Carita dengan Majalengka tidak berbeda nyata. Asal benih pada K3 menunjukkan bahwa asal benih tidak memberikan respon pertumbuhan diameter yang signifikan. Asal benih pada K4 menunjukkan bahwa asal benih Majalengka berbeda secara signifikan dengan asal benih Carita, sedangkan asal benih Carita dengan Sumedang dan asal benih Majalengka dengan Sumedang tidak berbeda secara signifikan (Tabel 6).

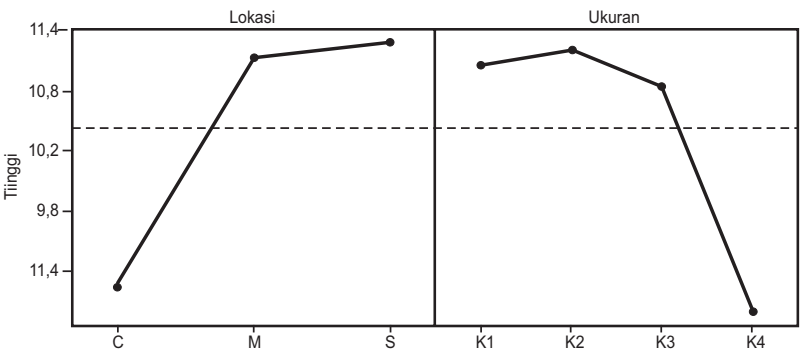

Plot faktor utama (Plot of main factor)

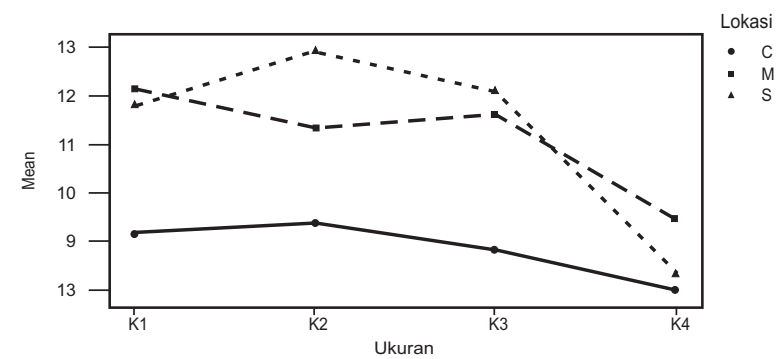

Plot interkasi antar faktor (Plot of interaction between factors)

Gambar(Figure) 7. Plot faktor utama dan interaksi antar faktor terhadap tinggi bibit weru berdasarkan seleksi seed gravity table (Plot of main factor and interaction between factors for seedling height of weru on seed size using seed gravity table) 


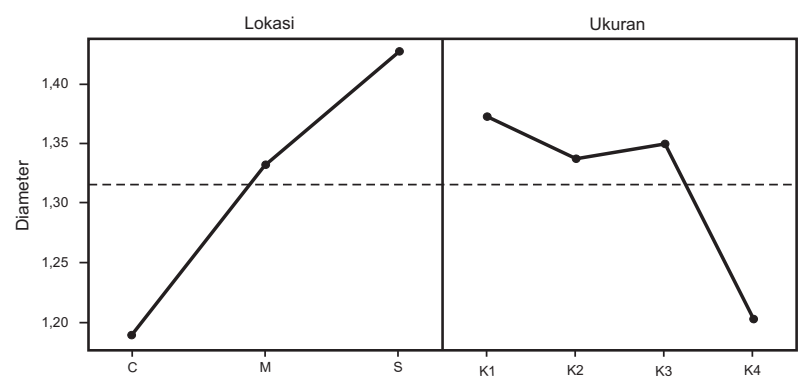

Plot faktor utama

(Plot of main factor)

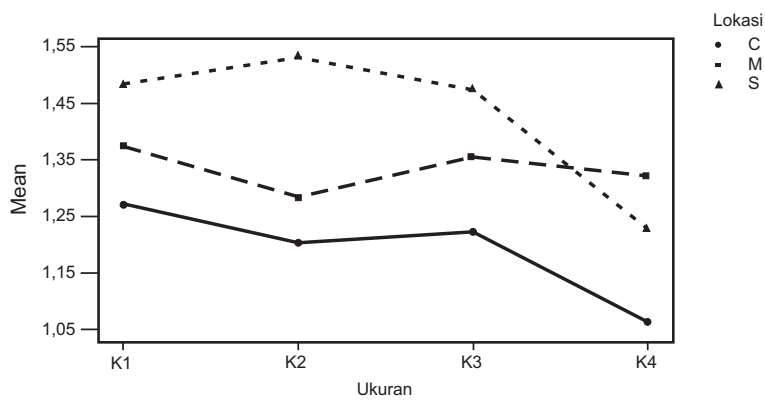

Plot interkasi antar faktor (Plot of interaction between factors)

Gambar (Figure) 8. Plot faktor utama dan interaksi antar faktor terhadap diameter bibit weru berdasarkan seleksi SGT (Plot of main factor and interaction between factors for seedling diameter of weru on seed size using SGT)

Pertumbuhan tinggi bibit weru yang terbaik berdasarkan ukuran benih yang diseleksi dengan alat SGT adalah benih asal Sumedang, kemudian diikuti Majalengka dan Carita, dengan ukuran benih K1, K2 dan K2. Pertumbuhan diameter bibit weru berdasarkan ukuran benih yang diseleksi dengan alat SGT tidak berbeda nyata. Tinggi bibit benih asal Sumedang yang tertinggi yang diikuti asal benih Majalengka dan Carita, dengan ukuran benih $\mathrm{K} 1$, $\mathrm{K} 2$ dan $\mathrm{K} 2$.

Hasil analisis plot interaksi antar asal benih dan ukuran benih berdasarkan seleksi dengan alat saringan (mesh) terhadap tinggi bibit weru terjadi interaksi yang signifikan, sedangkan terhadap diameter tidak ada interaksi (Gambar 9 dan 10).
Hasil uji lanjut asal benih pada ukuran benih 44,7 $\mathrm{mm}$ dan $>4,7 \mathrm{~mm}$ menunjukkan bahwa asal benih Carita berbeda secara signifikan dengan asal benih Majalengka dan Sumedang, namun tinggi bibit asal benih Majalengka dengan Sumedang tidak berbeda secara signifikan. Asal benih pada ukuran benih $<4 \mathrm{~mm}$ menunjukkan bahwa tinggi bibit asal benih Majalengka berbeda secara signifikan dengan asal benih Carita, namun tinggi bibit antara asal benih Majalengka dengan Sumedang, dan antara asal benih Carita dengan Sumedang tidak berbeda nyata. Khusus untuk diameter menunjukkan asal benih pada ukuran benih $<4$ $\mathrm{mm}, 4-4,5 \mathrm{~mm}$ dan $<4,7 \mathrm{~mm}$ tidak berbeda secara signifikan (Tabel 7).

Tabel (Table) 7. Rekapitulasi hasil uji-Tukey untuk rata-rata pertumbuhan tinggi dan diameter bibit weru berdasarkan klasifikasi ukuran benih menggunakan alat saringan (Recapitulation of Tukey test for the average of seedling height and seedling diameter of weru based on seed size classfication by using seed sieve)

Asal benih

(Provenances)

\begin{tabular}{lcccccc} 
& \multicolumn{1}{c}{$<$} & $4-4,7$ & $>4,7$ & $<4$ & $4-4,7$ & $>4,7$ \\
\hline Carita & $6,84 \mathrm{~b}$ & $7,93 \mathrm{~b}$ & $7,58 \mathrm{~b}$ & $0,68 \mathrm{a}$ & $0,74 \mathrm{a}$ & $0,74 \mathrm{a}$ \\
Majalengka & $8,77 \mathrm{a}$ & $9,70 \mathrm{a}$ & $10,50 \mathrm{a}$ & $0,75 \mathrm{a}$ & $0,73 \mathrm{a}$ & $0,88 \mathrm{a}$ \\
Sumedang & $7,77 \mathrm{ab}$ & $9,69 \mathrm{a}$ & $10,55 \mathrm{a}$ & $0,69 \mathrm{a}$ & $0,79 \mathrm{a}$ & $0,81 \mathrm{a}$ \\
\hline
\end{tabular}

Catatan (Note): Angka yang diikuti oleh huruf yang sama pada kolom yang sama tidak berbeda nyata pada tingkat kepercayaan 95\% (Figure followed by the same letters at column the same are not significantly different at $95 \%$ confident level) 


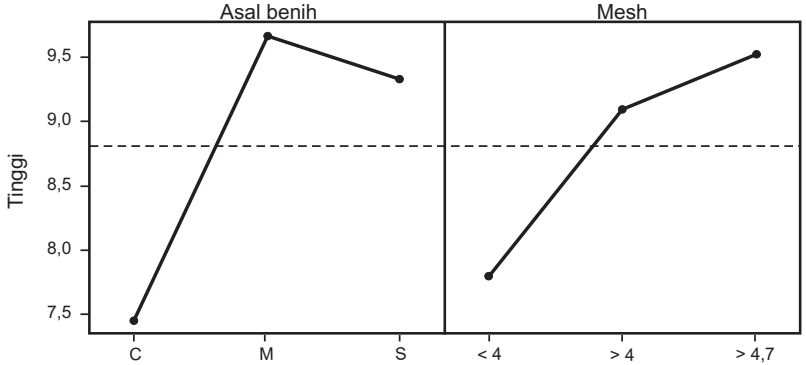

Plot faktor utama

(Plot of main factor)

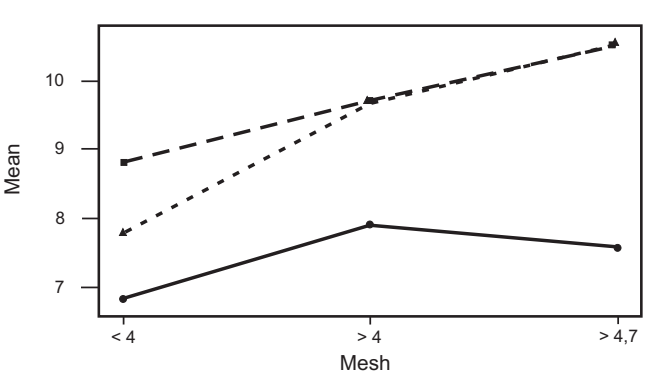

Plot interkasi antar faktor (Plot of interaction between factors)

Gambar(Figure) 9. Plot faktor utama dan interaksi antar faktor terhadap tinggi bibit weru berdasarkan seleksi alat saringan (Plot of main factor and interaction between factors for seedling height of weru on seed size using seed sieve in mesh)

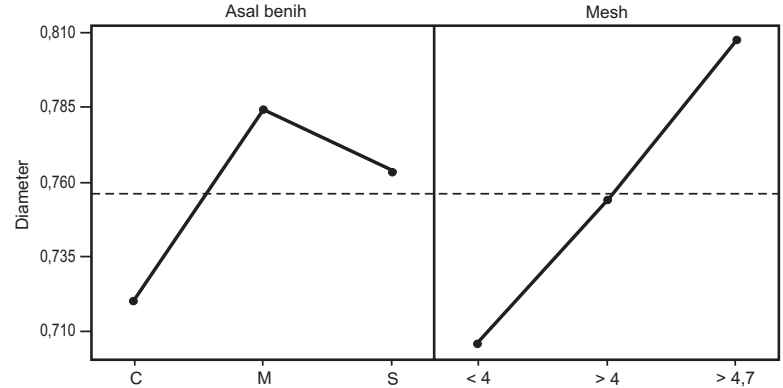

Plot faktor utama

(Plot of main factor)

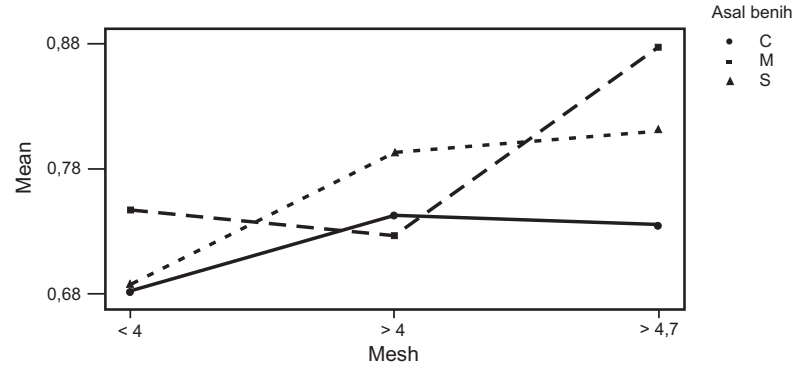

Plot interkasi antar faktor

(Plot of interaction between factors)

Gambar(Figure) 10. Plot faktor utama dan interkasi antar faktor terhadap diameter bibit weru berdasarkan seleksi alat saringan (Plot of main factor and interaction between faktors for seedling diameter of weru on seed size using seed sieve in mesh)

Pertumbuhan tinggi bibit weru di atas ratarata berasal dari benih Sumedang dan Majalengka, dengan ukuran benih 4-4,7 $\mathrm{mm}$ dan $>4,7$ $\mathrm{mm}$. Pertumbuhan diameter bibit weru yang dise- leksi dengan saringan (mesh), pertumbuhan diameter bibit di atas rata-rata yaitu benih asal Sumedang dan Majalengka dengan ukuran benih $>4,7 \mathrm{~mm}$.

Tabel (Table) 8. Rekapitulasi hasil uji-Tukey untuk rata-rata daya kecambah dan kecepatan berkecambah benih weru berdasarkan seleksi benih dengan alat SGT (Recapitulation of Tukey test for the average of germination percentage and speed of germination of weru based on seed selected using seed gravity table SGT)

\begin{tabular}{lcccccccc}
\hline \multirow{2}{*}{$\begin{array}{c}\text { Asal benih } \\
\text { (Provenances })\end{array}$} & \multicolumn{3}{c}{$\begin{array}{c}\text { Daya kecambah } \\
\text { (Germination percentage })\end{array}$} & \multicolumn{4}{c}{$\begin{array}{c}\text { Kecepatan berkecambah } \\
\text { (Speed of germination })\end{array}$} \\
\cline { 2 - 9 } & K1 & K2 & K3 & K4 & K1 & K2 & K3 & K4 \\
\hline Carita & $19,500 \mathrm{~b}$ & $29,750 \mathrm{~b}$ & $19,750 \mathrm{~b}$ & $6,750 \mathrm{a}$ & $2,330 \mathrm{~b}$ & $3,2925 \mathrm{~b}$ & $2,463 \mathrm{~b}$ & $0,800 \mathrm{a}$ \\
Majalengka & $54,250 \mathrm{a}$ & $58,750 \mathrm{a}$ & $43,250 \mathrm{a}$ & $11,000 \mathrm{a}$ & $6,243 \mathrm{a}$ & $6,7925 \mathrm{a}$ & $5,860 \mathrm{a}$ & $1,458 \mathrm{a}$ \\
Sumedang & $63,250 \mathrm{a}$ & $60,250 \mathrm{a}$ & $47,250 \mathrm{a}$ & $11,000 \mathrm{a}$ & $6,967 \mathrm{a}$ & $7,4100 \mathrm{a}$ & $6,178 \mathrm{a}$ & $1,678 \mathrm{a}$ \\
\hline
\end{tabular}

Catatan (Note): Angka yang diikuti oleh huruf yang sama pada kolom yang sama tidak berbeda nyata pada tingkat kepercayaan 95\% (Figure followed by the same letters at column the same are not significantly different at $95 \%$ confident level) 
Hasil analisis plot interaksi antar asal benih dan ukuran benih berdasarkan seleksi alat SGT terhadap daya kecambah dan kecepatan berkecambah benih weru terjadi interaksi yang signifikan (Gambar 11 dan 12). Hasil uji lanjut asal benih pada $\mathrm{K} 1, \mathrm{~K} 2$, dan $\mathrm{K} 3$ menunjukkan bahwa daya kecambah benih weru dan kecepatan berkecambah benih weru asal Carita berbeda secara signifikan dengan asal benih Majalengka dan Sumedang, sedangkan asal benih Majalengka dengan Sumedang tidak berbeda secara signifikan. Asal benih pada K4 menunjukkan bahwa daya kecambah dan kecepatan berkecambah benih weru antar asal benih Carita, Maja- lengka, dan Sumedang tidak berbeda secara signifikan (Tabel 8).

Daya berkecambah benih weru yang diseleksi dengan alat SGT, daya kecambah tertinggi terdapat pada benih asal Sumedang, kemudian diikuti Majalengka dan terendah Carita, dengan ukuran K1, K2 dan K3 mempunyai daya berkecambah di atas rata-rata.

Daya berkecambah, kecepatan berkecambah benih weru yang diseleksi dengan alat saringan (mesh) tidak berbeda nyata. Kecepatan berkecambah tertinggi adalah benih asal Sumedang, kemudian diikuti Majalengka dan terendah Carita, dengan ukuran K1, K2 dan K3.

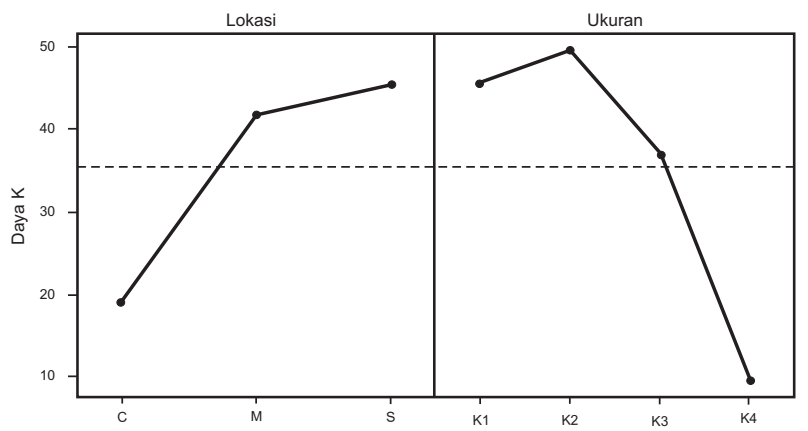

Plot faktor utama

(Plot of main factor)

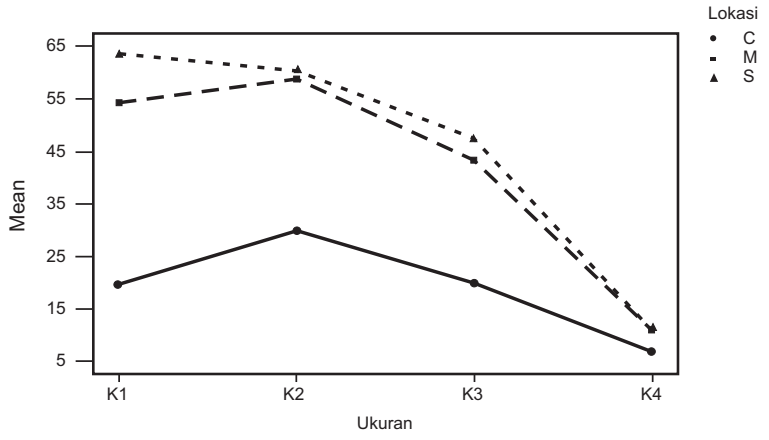

Plot interkasi antar faktor (Plot of interaction between factors)

Gambar(Figure) 11. Plot faktor utama dan interkasi antar faktor terhadap daya kecambah benih weru berdasarkan seleksi SGT (Plot of main factor and interaction between faktors for germination percentage of weru seed on seed size using SGT)

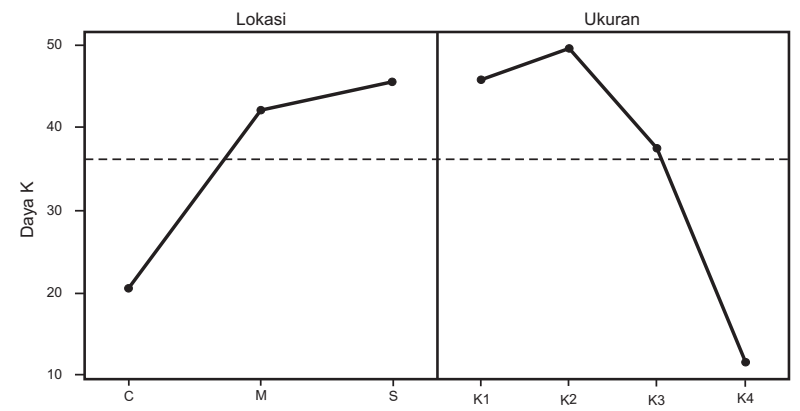

Plot faktor utama

(Plot of main factor)

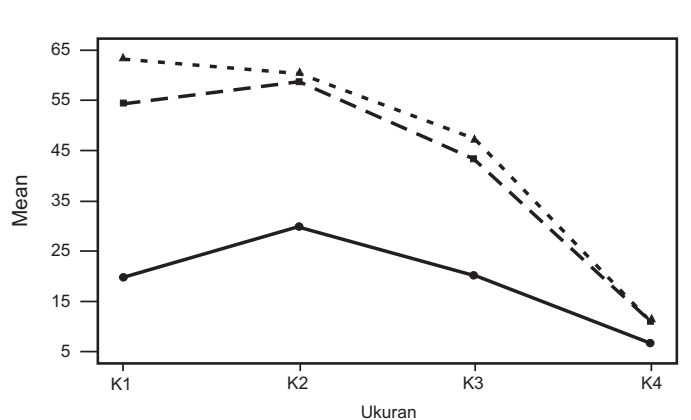

Plot interkasi antar faktor (Plot of interaction between factors)

Gambar (Figure) 12. Plot faktor utama dan interkasi antar faktor terhadap kecepatan berkecambah benih weru berdasarkan seleksi SGT (Plot of main factor and interaction between faktors for speed of germination of weru seed on seed size using SGT) 
Tabel (Table) 9. Rekapitulasi hasil uji-Tukey untuk rata-rata daya kecambah dan kecepatan berkecambah benih weru berdasarkan seleksi benih dengan alat saringan (Recapitulation of Tukey test for the average of germination percentage and speed of germination of weru based on seed selected by using seed sieve in mesh)

\begin{tabular}{lcc}
\hline $\begin{array}{c}\text { Asal benih } \\
\text { (Provenances) }\end{array}$ & $\begin{array}{c}\text { Daya kecambah } \\
\text { (Germination percentage) }\end{array}$ & $\begin{array}{c}\text { Kecepatan berkecambah } \\
\text { (Speed of germination) }\end{array}$ \\
\hline Carita & $25,330 \mathrm{~b}$ & $2,837 \mathrm{~b}$ \\
Majalengka & $49,50 \mathrm{a}$ & $6,163 \mathrm{a}$ \\
Sumedang & $49,25 \mathrm{a}$ & $5,832 \mathrm{a}$ \\
\hline
\end{tabular}

Catatan (Note): Angka yang diikuti oleh huruf yang sama pada kolom yang sama tidak berbeda nyata pada tingkat kepercayaan 95\% (Figure followed by the same letters at column the same are not significantly different at $95 \%$ confident level)

Hasil analisis menunjukkan faktor asal benih berbeda yang berpengaruh nyata terhadap daya kecambah dan kecepatan berkecambah benih weru, namun terhadap faktor ukuran benih dan tidak terjadi interaksi antara faktor asal benih dengan ukuran benih. Hasil uji perbandingan rata-rata daya kecambah dan kecepatan berkecambah benih weru menunjukkan asal benih $\mathrm{Ca}$ rita berbeda signifikan dengan asal benih Majalengka dan Sumedang, sedangkan benih asal Majalengka dan Sumedang tidak berbeda nyata. Rekapitulasi hasil uji lanjut disajikan pada Tabel 9.

Daya berkecambah benih weru yang diseleksi dengan alat saringan (mesh), menunjukkan bahwa daya kecambah tertinggi untuk pada benih asal Majalengka, kemudian diikuti Sumedang dan terendah Carita. Kecepatan berkecambah benih weru yang diseleksi dengan alat saringan (mesh) menunjukkan bahwa kecepatan berkecambah tertinggi untuk benih asal Majalengka, kemudian diikuti Sumedang dan terendah Carita.

\section{B. Pembahasan}

Benih weru yang berasal dari Carita, Majalengka, dan Sumedang berturut-turut semakin berat, sebaliknya semakin besar kriteria ukuran benih berdasarkan alat seed gravity table (K1, $\mathrm{K} 2$, K3, dan K4), maka berat benih semakin ringan. Hal ini sesuai dengan hasil penelitian jenis pilang (Suita et al., 2010), kaliandra dan akor (Suita et al., 2011). Berat benih asal Sumedang termasuk berat benih yang relatif lebih berat, sedangkan yang terendah asal benih Carita. Secara umum bahwa semua semakin besar ukuran benih semakin berat. Kadar air benih asal Sumedang lebih rendah daripada benih asal Carita dan Majalengka. Dengan demikian, kadar air pada berbagai kriteria benih hasil seleksi dengan SGT menunjukkan kadar air benih asal
Sumedang relatif paling rendah, sedangkan kadar air benih yang tertinggi terdapat pada benih yang berasal dari Carita dengan ukuran benih K4. Diduga benih-benih ukuran K4 merupakan benihbenih yang masih muda, sehingga kadar air masih tinggi. Benih yang masih muda tidak baik untuk disimpan karena mempunyai kadar air yang tinggi.Umumnya benih yang lebih besar mempunyai kadar air yang lebih rendah, ini menunjukkan bahwa benih besar diperkirakan sudah tua dan kadar air sudah mencapai nilai kesetimbangan dan lebih siap disimpan, apabila dihubungkan dengan sifat benih jenis ini yang berwatak ortodoks, dimana benih ortodoks lebih baik disimpan dengan kadar air rendah. Sesuai hasil penelitian Zanzibar dan Supriyanto (1993) menunjukan bahwa benih sengon ukuran K1 dan K2 lebih siap disimpan bila dibandingkan dengan ukuran benih K3 dan K4 karena memiliki kadar air yang lebih rendah. Seperti diketahui bahwa benih yang berwatak ortodok dalam penyimpanannya dibutuhkan kadar air benih tetap rendah (Schmidt, 2000).

Respon terhadap pertumbuhan tinggi dan diameter bibit weru di persemaian menunjukkan bahwa asal benih Sumedang relatif lebih baik daripada asal Carita dan Majalengka. Tingkat pertumbuhan tinggi dan diameter bibit yang terbaik adalah ukuran benih $\mathrm{K} 2$, namun ukuran benih K2 dan K3 juga cukup tinggi, hanya ukuran K4 yang rendah, dan jika menggunakan alat saringan pertumbuhannya yang terbaik adalah benih yang berukuran diameter $>4,7 \mathrm{~mm}$, kemudian diikuti ukuran diameter $4-4,7 \mathrm{~mm}$ dan yang terendah terdapat pada ukuran diameter $<4 \mathrm{~mm}$. Hal ini mendukung hasil penelitian Suita et al. (2010) yang menyatakan bahwa benih yang berat dan berdiameter besar mempunyai pertumbuhan tinggi yang lebih baik. Suita et al. (2011) menyatakan bahwa benih yang besar dan sedang telah 
menghasilkan pertumbuhan tinggi bibit yang lebih baik daripada benih berukuran kecil. Benih berukuran besar lebih cepat berkecambah sehingga lebih cepat pertumbuhan tingginya. Hal ini, terjadi karena ukuran benih berkorelasi dengan vigor (Schmidt, 2000). Benih berukuran besar cenderung berkecambah lebih cepat dan menghasilkan semai yang lebih besar daripada benih yang berukuran kecil. Hal ini dikarenakan benih yang besar memiliki ukuran embrio dan cadangan makanan yang lebih besar, sehingga benih besar lebih cepat berkecambah dan mempengaruhi kecepatan pertumbuhan tinggi pada saat awal pertumbuhan. Begitu juga menurut Hawkins (1996) bahwa benih yang lebih berat mempunyai pertumbuhan yang lebih baik, hal ini disebabkan kecepatan berkecambah pada ukuran yang lebih berat lebih baik dibandingkan dengan benih ringan, sehingga energi pertumbuhannya masih berlangsung. Dengan demikian, benih berukuran lebih berat memiliki potensi yang lebih baik untuk perkembangan bibit siap tanam. Dengan demikian, parameter tinggi sebagai salah satu kriteria morfologi bibit perlu diperhatikan, selain diameter, penampakan daun, batang dan bentuk tunas, bentuk dan volume akar, dan potensi pertumbuhan akar.

Ukuran benih yang diseleksi dengan alat SGT menghasilkan daya berkecambah terbaik untuk benih asal Sumedang dan Majalengka dengan ukuran benih K2. Ukuran benih K2 asal Sumedang termasuk benih yang berat. Hal ini menunjukkan bahwa benih dengan ukuran berat menunjukkan daya berkecambah yang lebih baik karena benih tersebut mempunyai cadangan mekanan yang lebih banyak, sehingga berkecambah lebih baik. Dengan demikian, untuk seleksi benih yang baik adalah benih yang tergolong berat karena ukuran benih akan berkorelasi dengan vigor (Schmidt, 2000). Seperti pada benih tanjung yang berukuran besar (panjang 16,6-19,9 mm) dan sedang (panjang 14,0-16,5 mm) memiliki daya berkecambah yang lebih tinggi (94,67-98,67\%) dan lebih cepat berkecambah $(0,21-0,42 \%$ Kecambah Normal/et mal), sehingga lebih vigor dan tanaman tumbuh normal (Suita dan Nurhasybi, 2008). Hal ini mendukung pendapat (Sorensen dan Campbell, 1993; Schmidt, 2000) bahwa benih yang relatif berat/besar yang dipilih. Begitu juga menurut Suseno (1975) dalam Riskendarsyah (1986), menyatakan bahwa untuk spesies tertentu benih berat/besar mempunyai kualitas yang lebih baik daripada benih kecil.
Kualitas genetik benih adalah susunan dasar genetik atau pewarisan yang dibawa oleh benih menentukan potensi penampilan keturunannya : apabila potensi genetiknya jelek maka penampilannya akan tetap jelek yang tidak dapat dipengaruhi oleh lingkungan dan usaha-usaha silvikultur. Apabila potensi genetiknya baik, potensi ini akan muncul dengan penerapan metoda silvikultur yang sesuai (Schmidt, 2000). Dari hasil seleksi dengan alat Seed Gravity Table perkecambahan dan pertumbuhan yang terbaik adalah benih yang berasal dari Sumedang. Dengan demikian benih yang berasal dari lokasi ini diduga mempunyai kualitas genetik yang lebih baik karena dilihat dari ukuran benih yang lebih besar, perkecambahn dan pertumbuhan bibit yang lebih baik.

Benih weru asal Sumedang merupakan benih yang lebih baik daripada asal Carita dan Majalengka. Hal ini dikarenakan, benih asal Sumedang relatif lebih berat, kadar air benih relatif lebih rendah, respon pertumbuhan tinggi dan diameter bibit weru di persemaian lebih baik, serta daya kecambah dan kecepatan berkecambah lebih tinggi dibandingkan dengan asal Carita dan Majalengka. Ukuran benih yang dapat dipilih jika menggunakan alat SGT yang terbaik adalah ukuran benih kelompok 2 (K2). Apabila menggunakan alat seleksi saringan/mesh, maka yang benih yang terbaik adalah benih ukuran $>4,7$ $\mathrm{mm}$, tetapi ukuran benih berdiameter $48-4,7 \mathrm{~mm}$ bisa juga digunakan.

\section{KESIMPULAN DAN SARAN}

\section{A. Kesimpulan}

Seleksi benih apabila menggunakan alat seed gravity table (SGT) yang terbaik adalah kelompok benih 2 (K2) dan apabila menggunakan alat saringan (mesh) ter-baik adalah ukuran benih berdiameter $>4,7 \mathrm{~mm}$. Benih weru asal Sumedang merupakan benih yang lebih baik daripada asal Carita dan Majalengka. Hal ini dikarenakan, benih asal Sume-dang relatif lebih berat, kadar air benih lebih rendah, respon pertumbuhan tinggi dan diameter bibit di persemaian lebih baik, serta daya kecam-bah dan kecepatan berkecambah lebih tinggi dibandingkan dengan asal Carita dan Majalengka.

\section{B. Saran}

Alat seed gravity table (SGT) harganya mahal tetapi kapasitas seleksinya besar sehingga lebih 
tepat digunakan penyedia benih skala besar sehingga lebih ekonomis. Namun alat seleksi saringan (mesh) investasinya rendah sehingga cocok digunakan oleh penyedia benih skala kecil.

\section{DAFTAR PUSTAKA}

Direktorat Perbenihan Tanaman Hutan [DPTH]. 2002. Petunjuk Teknis Pengujian Mutu Fisik-Fisiologi Benih. Direktorat Jenderal Rehabilitasi Lahan dan Perhutanan Sosial. Departemen Kehutanan.

Hartoyo dan T. Nurhayati. 1976. Rendemen dan Sifat Arang Beberapa Jenis Kayu Indonesia. Laporan No 62. Lembaga Penelitian Hasil Hutan. Badan Penelitian dan Pengembangan Pertanian Departemen Pertanian. Bogor.

Hawkins, B.J. 1996. Planting Stock Quality Assessment. In Yapa, A.C., ed. 1996. Proc. Intl. Symp. Recent Advances in Tropical Tree Seed Technol. and Planting Stock Production. ASEAN Forest Tree Seed Centre, Muaklek, Saraburi, Thai-land.

Heyne, K. 1987. Tumbuhan Berguna Indonesia (Jilid II). Badan Penelitian dan Pengembangan Kehutanan. Departemen Kehutanan. Jakarta. (terjemahan).

ISTA. 2006. International Rules for Seed Testing: Edition 2006. The International Seed Testing Association. Bassersdorf. Switzerland.

Riskendarsyah, A. 1986. Pengaruh Ukuran dan Saat Perekahan Buah dalam Proses Ekstraksi terhadap Viabilitas Benih Mahoni (Swietenia macrophylla King). LUC No. 8. Direktorat Jenderal Reboisasi dan Rehabilitasi Lahan. Departemen Kehutanan. Bogor.

Sadjad, S., E. Muniarti, dan S. Ilyas. 1999. Parameter Pengujian Vigor Benih Komparatif ke Simulatif. Jakarta: PT. Grasindo.

Schmidt, L. 2000. Pedoman Penanganan Benih Tanaman Hutan Tropis dan Subtropis. Terjemahan. Kerjasama Direktorat Jenderal Rehabilitasi Lahan dan Perhutanan Sosial dengan Indonesia Forest Seed Project. PT. Gramedia Jakarta.

Sorensen, F.C. and R.K. Campbell. 1993. Seed WeightSeedling Size Correlation in Coastal Douglas
Fir: Genetic and Enviromental Component. Canadian Jurnal of Forest Research. 23:2, 275285.

Steel, R.G.D. and J.H. Torrie. 1980. Principles and procedures of statistic. McGraw-Hill, Inc.

Syamsuwida, D. 2001. Kihiyang (Albizia procera), dalam Atlas Benih Tanaman Hutan Indonesia. Jilid II. Balai Teknologi Perbenihan. Bogor.

Sudrajat, D.J., E. Suita, E. Ismiati, E.R. Kartiana dan Abay. 2008. Standarisasi Pengujian Mutu Fisik dan Fisiologis Benih Tanaman hutan Jenis Kihiyang (Albizia procera) dan Sawo Kecik (Manilkara kauki). Laporan Hasil Penelitian. Balai Penelitian Teknologi Perbenihan. Bogor.

Suita, E. dan Nurhasybi. 2008. Pengaruh Ukuran Benih Terhadap Perkecambahan dan Pertumbuhan Bibit Tanjung (Mimusops elengi L.). Jurnal Manajemen Hutan Tropika. Vol. XIV (1). Fakultas Kehutanan. Institut Pertanian Bogor. Bogor.

, E. Ismiati dan P.G. Putra. 2010. Metode Seleksi dan Pendugaan Umur Simpan Benih Tanaman Hutan Penghasil Kayu Energi Jenis Weru (Albizia procera Benth) dan Pilang (Acacia leucophloea). Laporan Hasil Penelitian. Balai Penelitian Teknologi Perbenihan. Bogor.

T. Suharti, E. Ismiati, M. Sanusi, dan A. Priatna. 2011. Metode Seleksi dan Pendugaan Umur Simpan Benih Tanaman Hutan Penghasil Kayu Energi Jenis Kaliandra (Calliandra calothyrsus), Akor (Acacia auriculiformis), Weru (Albizia procera Benth), dan Pilang (Acacia leucophloea). Laporan Hasil Penelitian. Balai Penelitian Teknologi Perbenihan. Bogor.

Yulianti dan Nurhayati K. 1999. Pengaruh ukuran dan cara ekstraksi buah Khaya anthoteca terhadap perkecambahan serta mutu bibit. Buletin Teknologi Perbenihan. Vol 6(1). Badan Penelitian dan Pengembangan Kehutanan dan Perkebunan. Balai Teknologi Perbenihan. Bogor.

Zanzibar, M. dan A. Supriyanto. 1993. Penentuan Mutu Fisik dan Fisiologik Benih Sengon (Paraserianthes falcataria FOSBERG) dengan Menggunakan Alat Seed Gravity Table. Laporan Ujicoba (LUC) No 143. Balai Teknologi Perbenihan. Badan Litbang Kehutanan. Bogor. 